https://journal.literasisains.id/index.php/ABDIKAN ISSN xxxx-xxxx (Media Online) | ISSN xxxx-xxxx (Media Cetak) Vol. 1 No. 1 (Februari 2022) 33-39 DOI: $x x x x x$

\title{
Back to Nature - Toga Menjadi Produk Olahan Herbal yang Bernilai Ekonomis
}

\author{
Wita Oileri Tikirik $^{1}$, Jesika Turuallo ${ }^{2}$, Mardiana ${ }^{3}$, Nurfaiga Maulani ${ }^{4}$ \\ ${ }^{1,2,3,4}$ D-III Farmasi, STIKes Andini Persada, Mamuju, Indonesia \\ Email:wikutikirik@gmail.com
}

\begin{abstract}
TOGA is one of the best options to deal with health problems independently at home without having to come to a health facility as well as an effort to reduce the use of chemical drugs by returning to nature (back to nature). TOGA is very much needed in the current COVID-19 pandemic situation in order to break the chain of transmission by staying at home. The target family has a large yard which is planted with several medicinal plants. They know what plants are used as medicine, but their utilization has not been optimally and correctly and they do not know how to process TOGA into products of high economic value. The purpose of this activity is to provide information and knowledge regarding the proper and correct use of TOGA and how to process it into powders and herbs. We are students of KKN STIKes Andini Persada Mamuju doing one of the program activities is processing TOGA. The processing stages of making TOGA are by cooking with several plants including, ginger, temulawak, lemongrass, turmeric, the advantage of this processing is to obtain products in the form of herbs and powders by cooking and brewing.
\end{abstract}

Keywords: Health Problems, Herbs, TOGA

\begin{abstract}
Abstrak
TOGA merupakan salah satu pilihan terbaik untuk mengatasi masalah kesehatan secara mandiri di rumah tanpa harus datang ke fasilitas kesehatan sekaligus sebagai upaya untuk mengurangi penggunaan obat kimia dengan kembali ke alam (back to nature). TOGA sangat dibutuhkan pada situasi pandemi COVID19 sekarang ini guna memutus rantai penularannya dengan tetap di rumah saja. Keluarga binaan memiliki lahan pekarangan yang luas yang ditanami beberapa tanaman obat. Mereka mengenal tanaman apa saja yang digunakan sebagai obat, namun pemanfaatannya belum optimal secara tepat dan benar serta tidak mengetahui bagaimana mengolah TOGA menjadi produk bernilai ekonomi tinggi. Tujuan kegiatan ini untuk memberikan informasi dan pengetahuan terkait pemanfaatan TOGA secara tepat dan benar serta bagaimana cara mengolahnya menjadi serbuk dan jamu. Mahasiswa KKN STIKes Andini Persada Mamuju melakukan salah satu program kegiatan adalah pengolahan TOGA. Adapun tahapan pengolahan pembuatan TOGA yaitu dengan cara di masak dengan beberapa tanaman di antaranya, jahe, temulawak, sereh, kunyit, keuntungan dari pengolahan tersebut adalah memperoleh produk berupa jamu dan serbuk yang dapat dikonsumsi bagi semua kalangan masyarakat dan bernilai ekonomis.
\end{abstract}

Kata Kunci: Masalah Kesehatan, Herbal, TOGA.

\section{A. PENDAHULUAN}

Corona Virus Disease atau yang biasa dikenal dengan sebutan COVID-19 adalah suatu jenis penyakit baru yang belum pernah diidentifikasi sebelumnya pada manusia. COVID-19 merupakan keluarga besar virus yang menyebabkan penyakit ringan sampai berat bahkan dapat mengakibatkan kematian. Beberapa gejala diantaranya seperti common cold atau pilek, flu, radang tenggorokan, demam tinggi, nyeri otot dan penyakit yang serius seperti MERS dan SARS (Pakaya et al. 2021).

Berdasarkan data Pusat Krisis Kesehatan (PKK) Kemenkes RI sampai tanggal 13 April 2020 Indonesia terkonfirmasi ada 4.557 kasus, meninggal 399, dan sembuh 380 orang. Padahal pada tanggal 3 Maret 2020 ketika ditemukan pertama kali hanya ada 2 kasus terinfeksi corona virus (COVID-19) dan dua orang tersebut telah dinyatakan sembuh. Jumlah kasus yang dikonfirmasi terus tumbuh secara eksponensial, WHO menandai peristiwa monumental ini dengan mengingatkan semua negara dan 
komunitas bahwa melakukan kegiatan pencegahan dan pengendalian yang kuat agar dapat secara signifikan memperlambat atau menghentikan penyebaran virus ini (Mubaroq and Halima 2021).

Pada masa pandemi COVID-19 beberapa tanaman herbal di percaya dalam mencegah COVID-19. Pemerintah cina menyatakan secara resmi bahwa obat tradisionalnya dapat meringankan gejala, mempercepat penyembuhan dan mengurangi angka kematian pada kasus COVID-19. Hasil penelitian Bioinformatika menunjukkan bahwa senyawa aktif dari herbal dapat berikatan dengan protein virus SARS-CoV-2 sehingga berpotensi sebagai substansi untuk mencegah atau mengobati covid-19. Bentuk upaya promosi dilakukan dalam hal ini, yang tidak terlepas dari upaya pemutusan mata rantai penularan dan menghentikan penularan, yang salah satunya dapat dilankukan dengan upaya peningkatan sistem imun tubuh (Nur et al. 2022).

Pengobatan tradisional dengan menggunakan tumbuhan telah dilakukan sejak dahulu secara turun temurun oleh masyarakat Indonesia. Meskipun pengobatan modern telah berkembang hingga ke daerah pedesaan, namun penggunaan tumbuhan sebagai obat masih tetap diminati masyarakat dan saat ini semakin berkembang. Sejak merebaknya COVID-19 ini, masyarakat harus lebih memperhatikan makan atau minuman yang akan dikomsumsi agar meningkatkan daya tahan tubuh ditengah masa pandemi COVID-19 dikarena virus ini menyerang sistem pertahanan tubuh yang lebih. Kekebalan tubuh yang kuat dipercaya akan menghindarkan diri dari terkena wabah virus tersebut. Masyarakat percaya bahwa menggunakan obat tradisional seperti jamu dari rimpang jahe, kunyit, temulawak atau kencur, dapat meningkatkan imunitas tubuh (Sepriani et al. 2020).

World Health Organization (WHO) merekomendasikan penggunaan obat tradisional termasuk obat herbal dalam pemeliharaan kesehatan masyarakat, pencegahan dan pengobatan penyakit, terutama untuk kronis, penyakit degeneratif dan kanker. Tanaman obat keluarga (TOGA) menjadi salah satu pilihan masyarakat untuk ditanam di lahan pekarangan, dengan pertimbangan karena dapat dimanfaatkan untuk kesehatan. Tanaman obat dapat dijadikan obat yang aman, tidak mengandung bahan kimia, murah, dan mudah didapat. Pemanfaatan obat tradisional tersebut sebagai upaya untuk pemeliharaan kesehatan, pencegahan penyakit dan perawatan kesehatan termaksud pada masa kedaruratan kesehatan masyarakat dan atau bencana nasional Corona Virus Disease 2019 (COVID 19) (Pertiwi, Notriawan, and Wibowo 2020).

Dalam pandemi Covid-19 ini, TOGA berperan sangat penting karena beberapa dari tanaman obat bisa dibuat menjadi minuman herbal yang memiliki manfaat menyembuhkan demam, sakit kepala, masuk angin, flu, maupun batuk. Alasan mengapa memilih program kerja ini dikarena lahan pekarangan rumah keluarga binaan rata-rata cukup luas dan masih belum banyak yang memanfaatkannya, juga masih banyak diantara warga yang menganggap bahawa tanaman obat hanya bermanfaat sebagai tanaman hias dan beberapa menajadi bumbu masakan. Maka dari itu TOGA berpotensi menjadi peran penting untuk mencegah Covid-19 di masyarakat yang memiliki lahan luas yang belum digunakan (W et al. 2020).

Berdasarkan uraian di atas, maka akan dilakukan kegiatan berupa Pengolahan Tanaman Obat Keluarga (TOGA) Menjadi Minuman Berkhasiat Yang Dapat Menjaga Kesehatan Tubuh Pada Masa Pandemi Covid-19, yang bertujuan untuk menambah pengetahuan, meningkatkan pemahaman mengenai manfaat dari TOGA, meningkatkan keterampilan mengolah TOGA menjadi minuman yang berkhasiat bagi tubuh di masa pandemi Covid-19, dan juga meningkatkan keterampilan untuk menanam TOGA di pekarangan rumah yang bernilai (Sepriani et al. 2021).

\section{B. PELAKSAAN DAN METODE}

Tahapan persiapan pelaksanaan kegiatan pengabdian masayarakat ini terlebih dahulu dilakukan survey, kemudian mengurus surat permohonan izin/rekomendasi pelaksanaan kegiatan pengabdian masayarakat ini. Pada tahapan pelaksanaan terlebih dahulu melakukan kunjungan ke rumah warga guna untuk melakukan observasi terkait pengetahuan dan kebiasaan masyarakat dalam menggunakan tanaman herbal yang mudah ditemukan disekitar pemukiman warga (Sepriani et al. 2020). Setelah melakukan kunjungan ke bebarapa rumah warga maka langkah selanjutnya menentukan keluarga binaan guna untuk dilakukan pengolahan dan Pemanfaatan Tanaman Obat Keluarga dimasa Pandemi Covid-19 program ini didesain untuk membuat salah satu percontohan pada masyarakat setempat, karena dapat diolah menjadi produk herbal yang berkhasiat dan bernilai ekonomis.

\section{HASIL DAN PEMBAHASAN}

Obat Covid-19 belum ditemukannya secara spesifik yang dapat digunakan untuk menyembuhkan penderita yang terinfeksi Covid-19. Terapi yang digunakan hanyalah untuk menghilangkan gejala yang muncul dan meningkatkan imunitas penderita agar kuat melawan virus tersebut. Pemerintah juga menghimbau seluruh masyarakat untuk meningkatkan imunitas tubuh agar terhindar dari infeksi Covid-19. Imunitas tubuh dapat ditingkatkan dengan menerapkan prilaku pola hidup 
sehat. Pola hidup sehat meliputi pola makan dengan asupan nutrisi yang seimbang, dan olahraga. Nutrisi tambahan dapat berupa mengkonsumsi rempah-rempah seperti minuman jahe dan kunyit (Nugraha 2015). Tanaman obat keluarga banyak digunakan sebagai bahan baku obat tradisional dan jamu, yang apabila dikonsumsi dapat meningkatkan kekebalan tubuh (immune system), karena tanaman ini mempunyai sifat spesifik sebagai tanaman obat yang bersifat pencegahan (preventif) dan promotif melalui kandungan metabolit sekunder contohnya seperti gingiro pada jahe dan santoriso pada temulawak yang mampu meningkatkan sistem kekebalan tubuh. Jamu tidak dapat menyembuhkan yaitu bersifat kuratif, namun lebih ke arah sebagai pencegahan dengan cara meningkatkan kekebalan tubuh, sehingga lebih bermanfaat untuk mencegah Covid-19 (Anwar and Fitriana 2021).

Tanaman obat keluarga (TOGA) adalah suatu tumbuhan yang ditanam oleh keluarga disekitar lingkungan rumah yang mempunyai khasiat penyembuhan sebagai apotek hidup yang dimanfaatkan oleh keluarga secara sederhana dan budidaya tanaman yang berkhasiat sebagai obat dalam rangka memenuhi kebutuhan keluarga akan obat- obatan. Pemanfaatan tanaman obat keluarga (TOGA) yang lebih alami oleh masyarakat Indonesia, secara turun- temurun sebagai warisan budaya bangsa. Tanaman obat tradisional digunakan dan dilaporkan secara empirik oleh masyarakat bermanfaat meningkatkan kesehatan dan pengobatan berbagai penyakit. Penggunaan tana- man obat secara tradisional semakin disukai karena efek samping yang rendah, efek yang saling mendukung dengan obat tradisional lain, lebih sesuai untuk berbagai penyakit metabolik dan degeneratif. Selain itu, obat tradisional dapat diperoleh, diramu dan ditanam sendiri tanpa tenaga medis (Sari et al. 2015).

Setelah memberikan pengenalan mengenai pengertian, manfaat, dan jenis-jenis tanaman obat berkhasiat baik dalam bentuk gambar maupun secara langsung. Selanjutnya adalah memberikan cara pengolahan TOGA, Jenis tanaman obat yang dipilih yaitu tanaman jahe,temulawak, kunyit, temulawak dan sereh yang kemudian diolah secara sederhana menjadi minuman berkhasiat bagi tubuh khususnya pada masa pandemi Covid-19. Dalam kegiatan ini masyarakat ditingkatkan kemampuannya dalam mencari solusi untuk masalah kesehatan secara mandiri sebagai upaya pertolongan pertama dalam keluarga dan memelihara kesehatan melalui pemanfaatan toga, diharapkan dapat menunjang kesehatan kepada keluarga binaan sebagai upaya preventif, promotif, dan kuratif guna untuk peningkatan kesejahteraan serta sebagai sumber penyedia bahan baku tradisional (Oktarlina and Oktarlina 2021).

\section{Proses pengolahan}

Cara membuat obat tradisional yang terbuat dari bahan utamanya yaitu kunyit, jahe, temulawak dan sereh adapun bahan tambahanya yaitu bawang putih dan gula merah yang berfungsi meningkatkan imun tubuh dan meredakan batuk. Jahe diikenal sebagai bahan utama pembuatan minuman herbal yang mampu menghangatkan tubuh, meningkatkan imunitas tubuh (Sepriani et al. 2020). Terutama pada era di pandemi Covid 19, mengonsumsi minuman herbal dapat membuat tubuh anda terasa lebih hangat sehingga menjadi lebih nyaman.

\section{Penyortiran TOGA}

Penyortiran harus segera dilakukan setelah bahan selesai panen, terutama untuk bahan-bahan yang akan diolah menjadi minuman herbal seperti: kunyit, temulawak, jahe, sereh. rimpang yang baik dan yang busuk harus segerah dipisahkan juga tanah, pasir maupun gulma yang menempel harus segera dibersihkan.

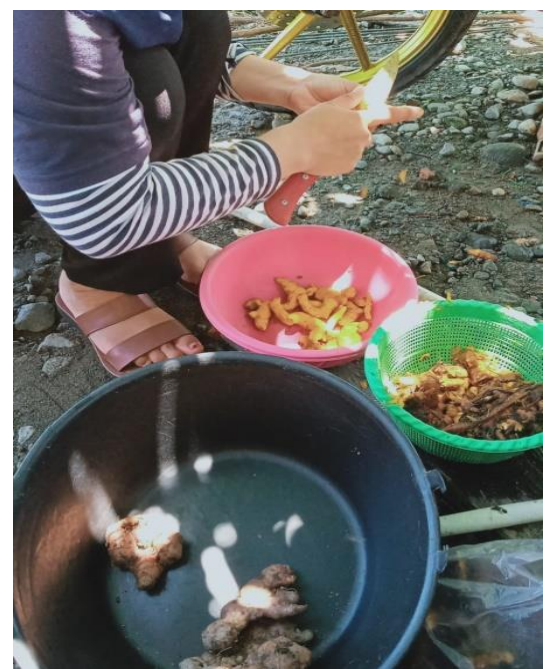

Gambar 1. Proses Penyortiran tanaman-tanaman yang akan digunakan 


\section{Pencucian}

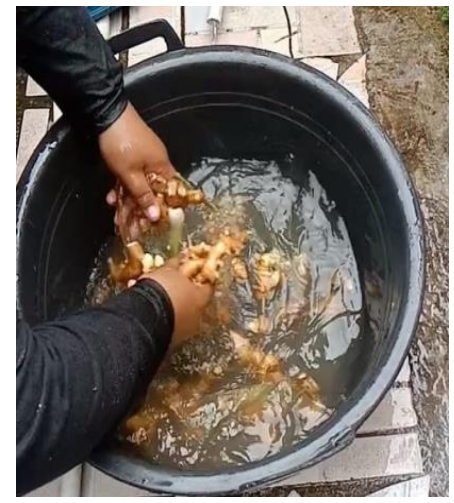

Gambar 2. Pencucian tanaman yang akan digunakan

Setelah disortir bahan harus segerah dicuci sampai bersih jangan dibiarkan tanah berlama-lam menempel pada rimpang karena dapat mempengaruhi mutu bahan. Pencucian harus menggunakan air bersih, seperti air dari mata air, sumur atau PAM. Cara pencucian dapat dilakukan dengan cara digosok menggunakan tangan sampai bersih, perendaman tidak boleh terlalu lama karena zat-zat tertentu yang terdapat dalam bahan dapat larut dengan air sehingga mutu bahan menurun.

\section{Penirisan dan Pengeringan}

Selesai pencucian rimpang ditiriskan dirak-rak penegering. Hal ini dilakukan sampai bahan idak meneteskan air lagi. Untuk komoditas temu-temuan pengeringan rimpang dilakukan selama 5-10 menit dan cukup didalam ruangan saja.

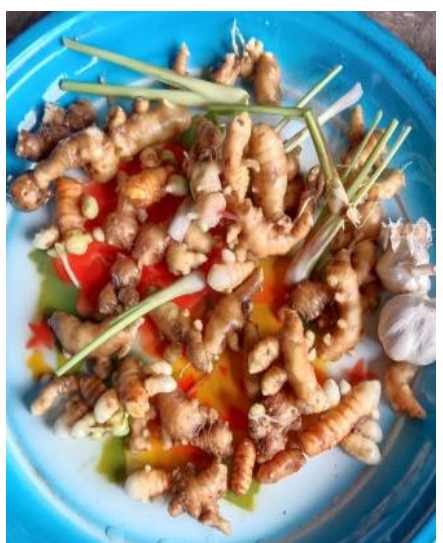

Gambar 3. Penirisan dan pengeringan tanaman didalam ruangan.

\section{Pemarutan}

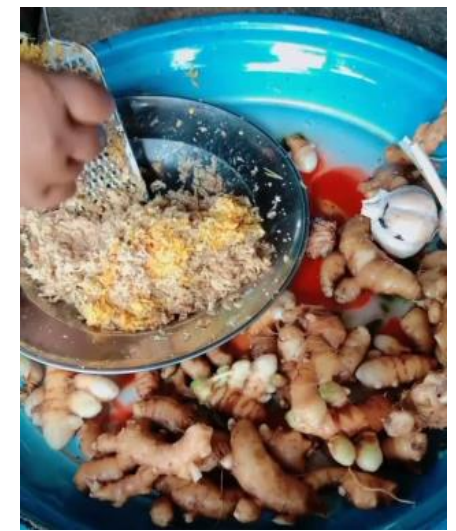

Gambar 4. Semua bahan diparut

Pemarutan bahan dilakukan untuk mempermudah campuran semua bahan, pengecilan ukuran bahan atau merusak dinding sel agar pati yang terdapat dalam sel keluar. 


\section{Penyaringan dan Penyeduhan Bahan}

Setelah semua bahan di parut bahan dicampurkan dengan air yang bersih dengan ketentuan tidak boleh terlalu jernih kemudian bahan di remas sekitar 1 menit, lalu di saring untuk memisahkan ampas dan air hasil perasan.

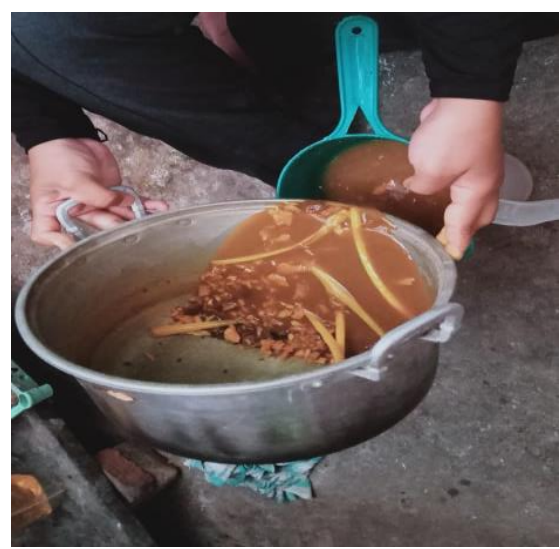

Gambar.5 Semua bahan disaring

Setelah bahan semua telah jadi, lalu direbus hingga mendidih dan mengental. Setelah itu lalu diseduh.

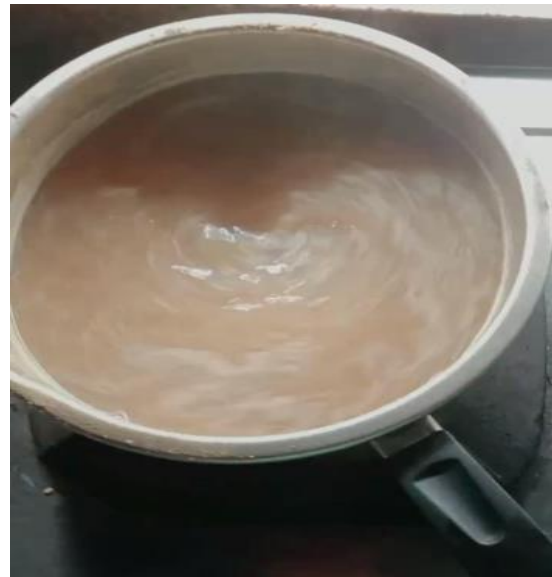

Gambar 6. Semua bahan direbus

\section{TOGA menjadi Produk Jamu dan Herbanase}

TOGA yang sudah diolah dibuat dalam bentuk jamu karena lebih mudah untuk didapat, harga terjangkau dan lebih tahan lama jika disimpan dalam lemari pendingin. Dan dapat juga dibuat dalam bentuk serbuk karena penggunaannya hampir semua orang dapat mengetahuinya dengan cara di seduh, pengolahannya juga lebih praktis karena semua bahan sudah tercampur, harga terjangkau, untuk menutupi bau dan rasa dari bahan yang pahit dan berbau (Anwar and Fitriana 2021).

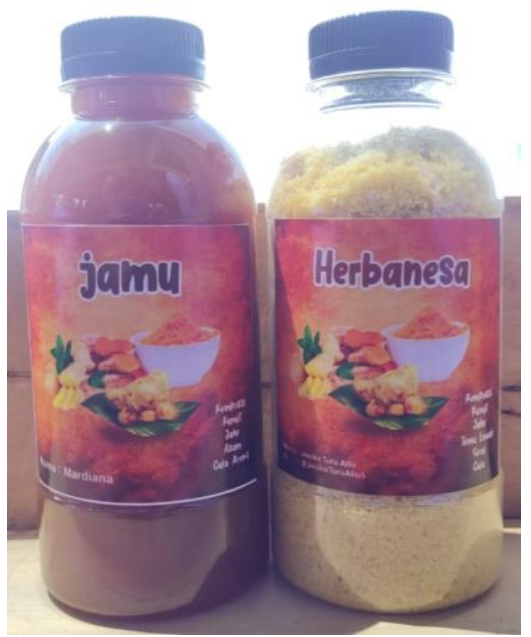

Gambar 7. Hasil Produk Olahan 
Pengembangan TOGA saat ini lebih pada aspek budidaya saja dengan pemanfaatan yang belum optimal dan terbatas pada diri serta keluarga saja. Masyarakat yang telah memiliki pengetahuan tentang khasiat TOGA dan menguasai cara pengolahannya dapat membudidayakan tanaman obat secara individual dan memanfaatkannya sehingga akan terwujud prinsip kemandirian dalam pengobatan keluarga.

Apalagi di masa pandemi Covid-19 ini, mengolah minuman herbal untuk menjaga kesehatan dengan bahan yang berasal dari hasil tanaman sendiri akan sangat membantu menjaga stabilitas ekonomi (Parawansah, Esso, and Saida 2020). Selain itu juga dapat dikembangkan menjadi usaha kecil dan menengah di bidang obat-obatan herbal seperti produk minuman herbal, pemanfaatannya dalam bentuk minuman herbal. Ada banyak hal yang harus diperhatikan dalam pengembangannya agar secara ekonomi bisa menambah penghasilan. Rasa, penampilan kemasan, perijinan, serta produk yang hidienis akan sangat penting dalam pengembangan produk minuman herbal dari TOGA (Sepriani et al. 2020)

\section{Saran}

Kami sangat berharap kepada pihak BPOM untuk dapat menindaklanjuti produk yang telah kami buat sebagai salah satu jamu dan serbuk untuk meningkatkan daya tahan tubuh di masa pandemi Covid-19.

\section{Ucapan Terima Kasih}

Kami dari tim pengabdian masyarakat STIKes Andini Persada mengucapkan terimakasih kepada seluruh pihak yang telah terlibat dan mendukung dalam proses kegiatan yang kami lakukan. Khususnya kepada seluruh masyarakat Desa Topore dan Desa Batusura yang telah mendukung kegiatan pengabdian masyarakat yang kami lakukan..

\section{E. DAFTAR PUSTAKA}

Anwar, Khoerul, and Mia Fitriana. 2021. "Pemberdayaan Masyarakat Dengan Pemanfaata Tanaman Obat Keluarga (TOGA) Dalam Pembuatan Jamu Untuk Meningkatkan Imunitas Tubuh Bagi Masyarakat Desa Sungai Besar Kabupaten Banjar Sebagai Pencegahan Covid-19.” Prosiding Seminar Nasional Pengabdian Kepada Masyarakat 3(1):1-6.

Mubaroq, Husni, and Nur Halima. 2021. "Peran Aktif Masyarakat Dalam Menanggulangi Penyebaran Covid-19 Di Kecamatan Kademangan Kota Probolinggo.” Journal of Governance and Policy Innovation 1(1):46-55.

Nugraha, Sumedi P. 2015. "Pelatihan Penanaman Tanaman Obat Keluarga (Toga)." Asian Journal of Innovation and Entrepreneurship 4(Vol 4, No 01 (2015): January 2015):58-62.

Nur, Akbar, I. Kadek Dwi, Swarjana Marlin, Nini Sahrianti, and Wita Oileri Tikirik. 2022. "Peningkatan Pengetahuan Masyarakat Tentang Pencegahan Covid-19 Di Desa Bambu Kabupaten Mamuju." 4(1):74-80.

Oktarlina, Rasmi Zakiah, and Afra Rahmania Santi Oktarlina. 2021. "Pemberdayaan Dan Pemanfaatan Toga Dalam Meningkatkan Sistem Imun Pada Masa Pandemi Covid-19 Di Kelurahan Nusantara Permai.” Buguh: Jurnal Pengabdian Kepada Masyarakat 1(1):30-37.

Pakaya, Ririn, Firdaus Ramadhani, Sunarti Hanapi, Franning Deisi Badu, and Ismelda Iyou. 2021. "Penerapan 3M Dalam Upaya Pencegahan Penularan Corona Virus Disease Di Desa Mohiloyo." Jurnal Pengabdian Kepada Masyarakat Universitas Gorontalo 3(1):34-38.

Parawansah, P., A. Esso, and S. Saida. 2020. "Sosialisasi Pemanfaatan Tanaman Obat Keluarga Sebagai Upaya Untuk Meningkatkan Imunitas Tubuh Ditengah Pandemi Di Kota Kendari." Journal of Community Engagement in Health 3(2):2018-21.

Pertiwi, Reza, Doni Notriawan, and Risky Hadi Wibowo. 2020. "Pemanfaatan Tanaman Obat Keluarga (TOGA) Meningkatkan Imunitas Tubuh Sebagai Pencegahan COVID-19.” Dharma Raflesia: Jurnal Ilmiah Pengembangan Dan Penerapan IPTEKS 18(2):110-18.

Sari, Ida Diana, Yuyun Yuniar, Selma Siahaan, Riswati Riswati, and Muhamad Syaripuddin. 2015. "Tradisi Masyarakat Dalam Penanaman Dan Pemanfaatan Tumbuhan Obat Lekat Di Pekarangan." Jurnal Kefarmasian Indonesia 5(2):123-32. 
Sepriani, Rika-, Eldawaty Eldawaty, Arie Asnaldi, Asep Sujana Wahyuri, and Kibadra Kibadra. 2020. "Pembuatan Jamu Serbuk Instan Berbasis Tanaman Obat Keluarga (Toga) Bagi Ibu-Ibu Pkk Di Kelurahan Tarantang Kecamatan Lubuk Kilangan Kota Padang.” Jurnal Berkarya Pengabdian Masyarakat 2(1):49-55.

Sepriani, Rika, Hilmainur Syampurma, Arie Asnaldi, Fakultas Ilmu Keolahragaan, and Universitas Negeri Padang. 2021. "Pemanfaatn TOGA Di Masa Pandemi Covid-19.” Journal Berkarya 3:5057.

W, Yulius Puguh A., Shinta Aulia R.D.F, Eliza Nadhia R, and Patria Tri H. 2020. "Pemanfaatan Toga Guna Meningkatkan Kesadaran Masyarakat Terhadap Toga.” Jurnal Abdi Bhayangkara UBHARA Surabaya 2(1):198-202. 